\title{
ARCHEOLOGICKÝ VÝSKUM HRADU GÝMEŠ V ROKOCH 2013-2014
}

\author{
MÁRIO BIELICH - JOZEF ELGYÜTT
}

\begin{abstract}
Abstrakt: Cielom príspevku je prezentovat' prvé čiastkové výsledky archeologického výskumu hradu Gýmeš v rokoch 2013-2014. Archeologický výskum sa uskutočnil súbežne s archtitektonicko-pamiatkovým výskumom M. Bónu. Sondy boli situované v priestore pôvodnej vstupnej gotickej brány, skalného tunela, hospodárskej budovy v hornom hrade a parkánového vstupu pod Kaplnkou sv. Ignáca. Z archeologického výskumu pochádza keramický materiál, ktorý sme zatial’ len čiastkovo zanalyzovali. Medzi nálezmi sa objavuje keramika, kachlice, drobné železné predmety a sklo. Nálezy dokumentujú históriu hradu od 13. do16. storočia.
\end{abstract}

Kl'účové slová: hrad Gýmeš - gotická brána - parkánový vstup - 13.-16. storočie.

\section{Archaeological Research into the Gýmeš Castle in 2013-2014}

Abstract: This contribution presents the first results of archaeological research into the Gýmeš castle in 2013-2014. The research was conducted in parallel with architectural and heritage research led by M. Bóna. Test pits were excavated in the area of the original Gothic main gate, a rocky tunnel, an outbuilding in the upper castle and the rampart entrance below the Chapel of St. Ignatius. The archaeological research yielded pottery that was partially analysed. Apart from pottery the finds include tiles, small iron items and glass, and document the history of the castle in the 13th-16th centuries.

Key words: Gýmeš castle - Gothic main gate-rampart entrance-13th-16th centuries.

\section{Úvod}

Hrad Gýmeš sa nachádza na juhozápadnom Slovensku v regióne Požitavia, ned’aleko krajského mesta Nitra. Zrúcanina stojí na skalnatom kremencovom vrchole kopca Dúň (514 m n. m.) na južnom svahu pohoria Tribeč. Stavitelia hradu využili prirodzenú obranyschopnost' vrcholu kopca, kde skalnaté podložie vystupuje na povrch a vytvára bralo približne tvaru ostrého trojuholníka so stranami 150, 140 a $80 \mathrm{~m}$, so špicom smerom na východ. Najlahší prístup je po asi $15 \mathrm{~m}$ širokej šiji pozdíž rovnako širokého skalného hrebeňa tiahnuceho sa smerom na juhozápad (obr. 1).

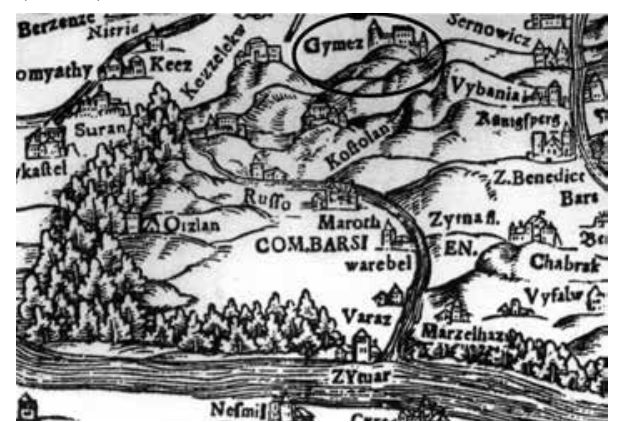

Obr. 1. Hrad Gýmeš, okr. Nitra. Najstaršie zobrazenie hradu na Lazarovej mape z prvej polovice 16. storočia. Dostupné z: http:// www.sulinet.hu/oroksegtar/data/kulhoni_magyarsag/2009 Gimes_evszazadai/pages/ge_006_a_gim-var.htm.

Abb. 1. Burg Gýmeš, Bezirk Nitra. Ä̈lteste Darstellung der Burg auf der Lazarus-Karte aus der ersten Hälfte des 16. Jhdts. Verfügbar unter: http://www.sulinet.hu/oroksegtar/data/kulhoni magyarsag/2009/Gimes_evszazadai/pages/ge_006_a_gim-var. htm.

rickému výskumu hradu intenzívne venuje M. Bóna, ktorý publikoval početné čiastkové štúdie o stavebnom vývoji hradu a je aj autorom stručnej monografie o Gýmeši (Bóna 1995; 1996; 2002;

Počiatky vedeckého záujmu o hrad môžeme pozorovat' už v 19. storočí. Okolo roku 1808 hrad navštívil barón Alojz Mednyánszky. Zaznamenáva, že hrad bol $\mathrm{v}$ tomto čase ešte $\mathrm{v}$ dobre udržiavanom stave (Mednyánszky 1821). Z roku 1887 pochádza prvá výskumná správa od Jozefa Könyökiho, obsahujúca detailný pôdorys hradu s popisom jednotlivých častí (Könyöki 1905). Kresby zachytávajú hrad už ako zrúcaninu so zrútenou klenbou hradnej kaplnky. Správa obsahuje aj kresby troch typov tehál so značkami a letopočtami. Gýmeš neobišla ani d'alšia významná osobnost' v oblasti výskumu hradov Dobroslava Menclová. V rámci svojej typologickej štúdie o slovenských hradoch priniesla prvú analýzu stavebného vývoja hradu (Menclová 1973). V súčasnosti sa architektonicko-histo- 
2003; 2003a; 2006; 2007; 2011). Historickému a archívnemu výskumu sa venovali J. Lukačka (2003) a M. Eliáš (2011). Z archeologického hl'adiska ide o dosial' prakticky neskúmanú lokalitu - s výnimkou povrchových zberov a menšieho sondážneho výskumu v roku 1984 v severnom rohu hradného Kostola sv. Ignáca, vyvolaného nelegálnym výkopom (Katkin-Bóna 2000). Od roku 2004 členovia občianskeho združenia Leustach organizovali dobrovol’nícke práce na hrade, zahŕňajúce najmä údržbu zelene a konzerváciu murív, vrátane čiastočnej obnovy hlavnej veže a zaklenutého prejazdu v juhozápadnom paláci podl'a projektu M. Bónu. Prvý systematický archeologický výskum uskutočnil Filip Jaššo (2011). V roku 2012 vzniklo občianske združenie Castrum Ghymes, ktorého aktivity metodicky vedie M. Bóna. V rámci archeologického výskumu boli v roku 2013 vykopané a preskúmané štyri sondy v štyroch rôznych objektoch hradu (obr. 2). Išlo o sondy v starej gotickej bráne (sonda 9), skalný tunel (sonda 10), vstup do pivnice (sonda 11) a bočný parkanový vstup (sonda 12). V roku 2014 sa pokračovalo pred vstupom do gotickej brány (sonda $9 \mathrm{v}$ sektore B) a v parkánovom vstupe (sonda 12C).

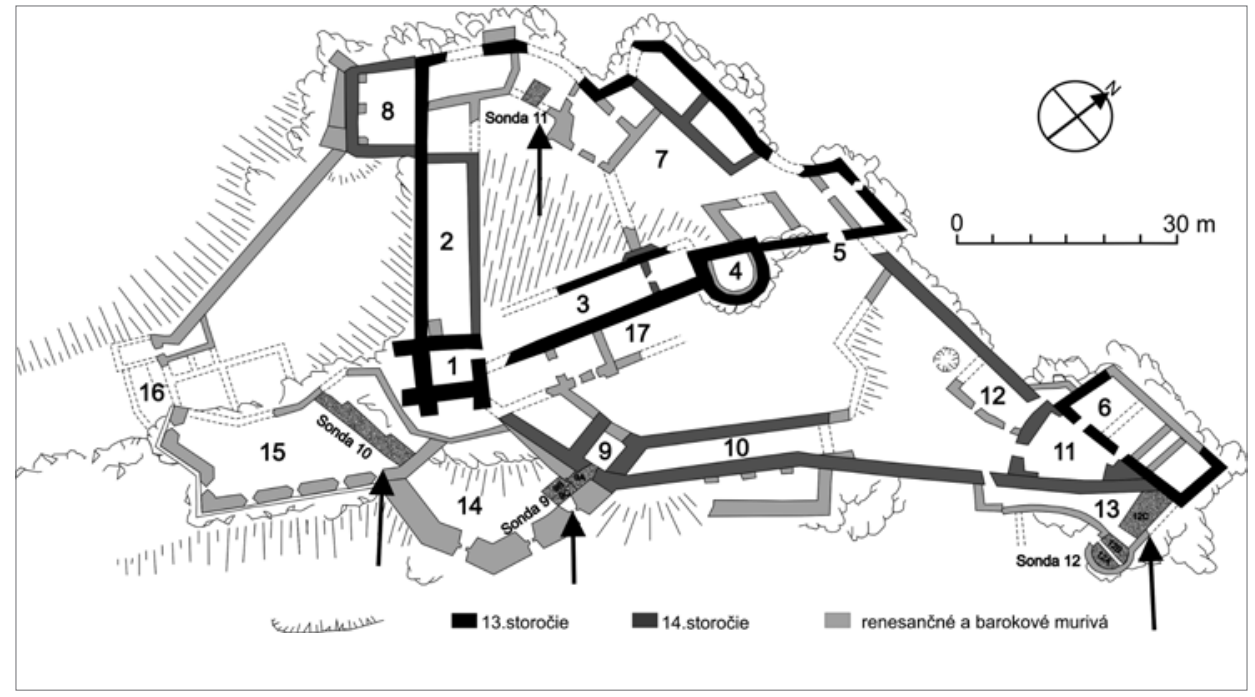

Obr. 2. Hrad Gýmeš, okr. Nitra. Pôdorys hradu s jednotlivými stavebnými fázami a s miestami, kde bol realizovaný archeologický výskum. 1 - 13. storočie, 2 - 14. storočie, 3 - renesančné a barokové murivá bez etapového rozlíšenia. Podl’a Plaček-Bóna $2007,123$. Abb. 2. Burg Gýmeš, Bezirk Nitra. Grundriss der Burg mit den einzelnen Bauphasen und den Stellen, an denen die archäologischen Grabungen erfolgten. 1 - 13. Jhdt., 2 - 14. Jhdt., 3 - renaissance- und barockzeitliches Mauerwerk ohne Etappenunterscheidung. Nach Plaček-Bóna 2007, 123.

\section{História hradu}

Stavba kamenného hradu sa pripisuje Ondrejovi, synovi Ivanka z rodu Huntovcov-Poznanovcov, zakladatel’ovi rodu Forgáčovcov. Prvýkrát sa hrad Gýmeš spomína v roku 1253, rodová tradícia uvádza rok vzniku 1250. V Zoborskej listine z roku 1113 sa spomínajú ,podhradčania“ v ned’alekých Kostol’anoch pod Tribečom - čo nepriamo naznačuje existenciu staršieho hradu v okolí. Okrem staršieho hradu na jeho dnešnom mieste prichádza do úvahy aj možnost', že týmto predchodcom mohol byt' Studený hrad, vzdialený $600 \mathrm{~m}$ južne od Gýmeša. Listina z roku 1274 uvádza, že hrad a jeho majitelia sa ubránili proti útoku českého krála Přemysla Otakara II. Z roku 1295 pochádza listina o delení hradu medzi štyroch Ondrejových synov: dozvedáme sa, že hrad tvorili dve veže, palác, opevnenie, cisterna a sýpka. $Z$ toho je zrejmé, že hrad mal už vtedy rozsah dodnes zachovaného hradného jadra s hlavnou hranolovou obytnou vežou - ranogotickým donžonom s piliermi, ktorý bol postavený podl’a francúzskych vzorov. Na túto vežu sa napájal dvojpodlažný obdížnikový palác a obytná veža s podkovovitým pôdorysom. Nádvorie 
hradu s cisternou a sýpkou (tie zatial' nie je možné presnejšie lokalizovat') bolo uzavreté hradbovým múrom. Palác vstavaný medzi dve veže je pre našu oblast'v 13. storočí progresívnym architektonickým riešením. Ďalšou pozoruhodnou informáciou z tejto listiny je, že najzámožnejší zo synov - Tomáš - sa rozhodol postavit' si samostatný hrad na skale východne od otcovského hradu. Môžeme ho stotožnit's gotickým palácom obdížnikového pôdorysu, tvoriacim pôvodne najvýchodnejšiu čast' hradu, z ktorého sa zachovala južná stena, severovýchodné nárožie a čast' západnej steny. Po roku 1303 hrad násilne získal Matúš Čák Trenčiansky a dosadil sem svojho kastelána. Pravdepodobne vtedy boli dva hrady, resp. hrad a samostatne stojaci Tomášov palác, spojené hradbou, čím vzniklo tzv. východné predhradie. Po Matúšovej smrti (1321) bol hrad pod správou král’ovských kastelánov. Forgáčovci ho získali naspät' v roku 1386. Podl’a listiny z roku 1412 je hrad rozdelený na vonkajší a vnútorný. Jedinou analógiou hradu s palácom medzi vežami v prostredí Uhorska v 13. storočí je hrad Siklós (Fügedi 1986, 116), častejšie sa táto dispozícia vyskytuje na hradoch stavaných v priebehu nasledujúceho 14. storočia (Dobrá Voda, Liptovský

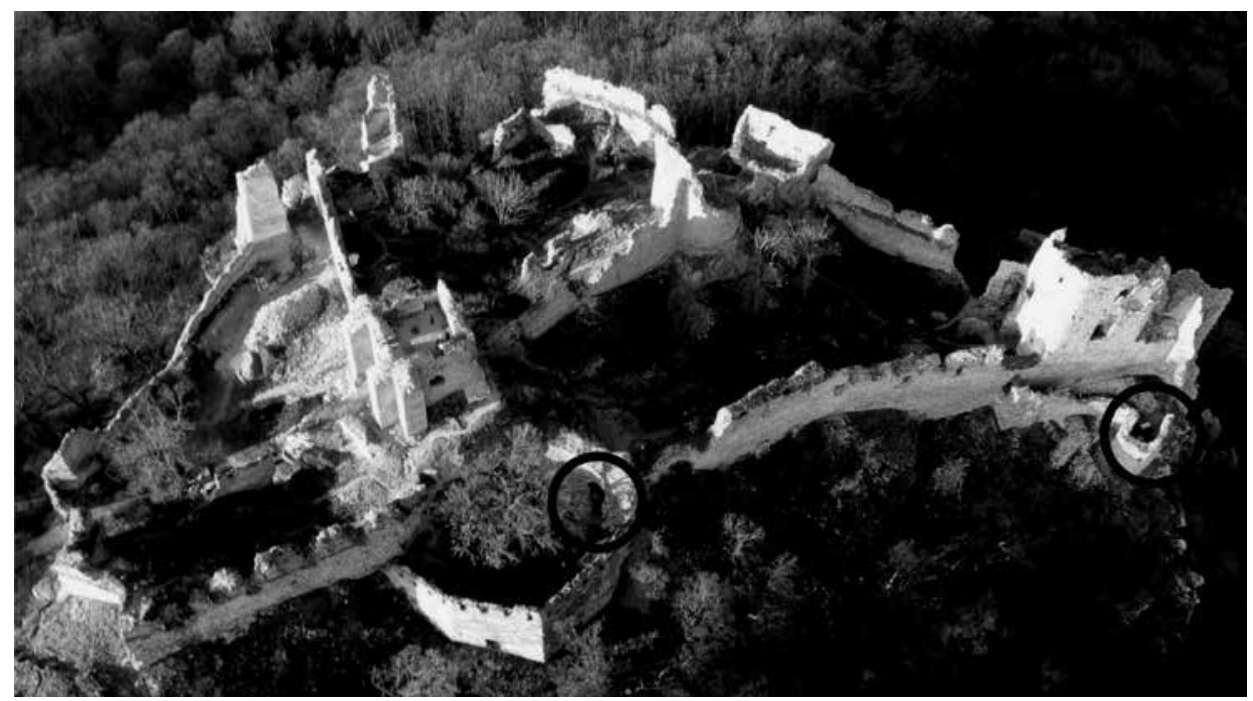

Obr. 3. Hrad Gýmeš, okr. Nitra. Letecký pohl'ad na hrad z východu. Archív Združenia Castrum Ghymes.

Abb. 3. Burg Gýmeš, Bezirk Nitra. Luftaufnahme von der Burg von Osten. Archiv der Vereinigung Castrum Ghymes.

Hrádok). Vnútorný hrad obsahoval vežu, paláce, opevnenia a rozostavané objekty, vo vonkajšom stála stredne vel'ká veža, Ditrichov palác, opevnenia, malá veža nad bránou a iné stavby. $\mathrm{Na}$ vnútornom hrade teda pribudol d'alší palác; nepochybne ide o dodnes čiastočne zachovaný tzv. juhozápadný palác. Uvedené rozostavané objekty môžeme stotožnit's hospodárskymi budovami pristavanými k severnej hradbe. Vonkajší hrad, čiže východné predhradie, obsahuje podl’a opisu „stredne vel'kú vežu“ - zrejme ide o obytnú vežu s podkovovitým pôdorysom, ked’že sa v rámci vnútorného hradu neuvádza, a svojím zaoblením vystupuje práve do východného predhradia. „Ditrichov palác“ je zrejme bývalý Tomášov palác na východnom konci hradu. Zmienka o „malej veži nad bránou“ dokladá, že v tomto čase bol vstup na hrad riešený prejazdovou vežovou bránou, ktorú je možné dodnes identifikovat’ v murivách v južnej časti východného predhradia. „Inými stavbami“ sú najskôr myslené hospodárske objekty pristavané k juhovýchodnej hradbe východného predhradia. K d’alšiemu deleniu hradu prišlo v roku 1504 . Hrad si vtedy rozdelili na polovice bratia Peter a Gregor Forgáčovci. V tom čase na hrade pribudli dva vežovité neskorogotické paláce - jeden štvorpodlažný, pristavaný na východnom brale z juhu k pôvodnému Tomášovmu palácu (dochovaný v barokovej prestavbe na hradnú kaplnku) a druhý, pristavaný zvonka k západnému nárožiu jadra (zachované len južné nárožie a čast' juhozápadnej 
steny). Na naliehanie král'a, ktorý trval na plnení povinností udržiavat' hrad kvôli jeho strategickému významu pri obrane krajiny, sa v roku 1562 uskutočnila nová del'ba Gýmeša medzi Petrom a Žigmundom Forgáčom. Hoci obaja spolu s rodinami bývali už v pohodlnejších kaštiel’och v Komjaticiach, hrad plnil funkciu rodinného archívu, skladu zásob a bezpečného útočiska v prípade ohrozenia. K významnej prestavbe hradu dochádza v poslednej tretine 16. storočia. Bolo vybudované južné predhradie, doplnené z iniciatívy Žigmunda II. Forgáča v roku 1613 delostreleckým bastiónovým opevnením, čím došlo k d’alšiemu premiestneniu hlavného vstupu do hradu na dnešné miesto. V roku 1619 poškodili hrad vojská Gabriela Betlena. V rokoch 1663 a 1671 ho nakrátko obsadili Turci. Obranyschopnost' hradu posilnili koncom 17. storočia uzatvorením juhovýchodného vstupu vel'kou polygonálnou delovou baštou. Z dôvodu pripojenia Šimona Forgáča na stranu Rákociho povstalcov bol hrad s panstvom nakrátko skonfiškovaný. Naspät' sa ho podarilo získat' v roku 1711 Pavlovi IV. Forgáčovi, ktorý so synom Pavlom V. uskutočnil vel'kolepú barokovú opravu a prestavbu hradu (1713-1755). Okrem toho v obci Jelenec dali postavit' kaštiel' a kostol. Vzhl'adom na to, že obaja boli cirkevní hodnostári, do popredia sa dostala najmä sakrálna funkcia hradu. Vo východnom predhradí zriadili sakrálnu čast' pútnické miesto, pričom za patróna si zvolili sv. Ignáca z Loyoly. Jemu zasvätili kostol, ktorý vznikol prestavbou neskorogotického štvorpodlažného paláca. Pod ním zriadili rodinnú kryptu Forgáčovcov. Ku kostolu boli zo severu a západu pristavané Kaplnky sv. Pavla a sv. Jána. Čast' ranogotického paláca bola prestavaná na sakristie. „Sakrálny okrsok“ bol oddelený od zvyšnej časti východného predhradia murovanou priečkou. Na takto vzniknutom malom nádvorí pred Kostolom sv. Ignáca bola bývalá cisterna, adaptovaná na Mariánsky prameň. V protil’ahlom juhovýchodnom rohu nádvoria bola v dodnes zachovanej nike umiestnená socha sv. Ignáca. Baroková prestavba sa dotkla aj d’alších častí hradu - juhozápadného paláca, bývalej juhovýchodnej vežovej brány a najmä hlavného vstupu do hradu z juhozápadu. Začiatkom 19. storočia bol hrad ešte obývatel'ný a každoročne sa sem konali púte. V roku 1814 pútnici našli kryptu vykradnutú. K celkovému spustnutiu hradu došlo v tridsiatych rokoch 19. storočia, pričom už v štyridsiatych rokoch bol bez striech (Plaček-Bóna 2007, 122-125).

\section{Archeologický výskum}

Na základe metodického postupu obnovy hradu Gýmeš, ktorú riadi M. Bóna, sme v rokoch 2013 a 2014 sondy situovali do najviac ohrozených stavieb na hrade. Archeologickým výskumom boli skúmané štyri sondy (S9-S12). Sondy boli umiestnené v objektoch hradu, pri ktorých dochádzalo k postupnej sanácii murív. Rozsah výskumných prác bol prispôsobený finančným možnostiam obnovy.

\section{Sonda 9/2013-2014}

Sonda sa nachádzala $v$ juhovýchodnom priestore hradu, medzi renesančnou delovou baštou a starou gotickou bránou. Bola rozdelená na tri sektory: A (interiér gotickej brány) a $\mathrm{B}, \mathrm{C}$ (exteriér gotickej brány). Sondy mali rozmery $500 \times 200 \mathrm{~cm}(9 \mathrm{~A})$ a $300 \times 300 \mathrm{~cm}(9 \mathrm{~B}, 9 \mathrm{C})$. Terén v mieste sondy 9A tvorila zväčša sut' zo spadnutej klenby hospodárskeho priestoru. Sondy 9B a 9C sa nachádzali na prudkom sut’ovom kuželi, ktorý vznikol rozpadom nadzemných podlaží brány a deštrukciou konštrukcií v priestore renesančného delového bastiónu (obr. 4). V sektore B v exteriéri brány sme sa snažili identifikovat’ tvar nárožia renesančného opláštenia vonkajšej steny brány. V sektore $\mathrm{C}$, umiestnenom napravo od vstupu, sme skúmali vzt’ah brány a delového bastiónu, čo súvisí s rozširovaním hradu na juh. Podarilo sa nám identifikovat' múr, ktorý by mohol byt' súčast'ou schodiska alebo prepojenia brány s ochodzou delostreleckého bastiónu. V sektore A, ktorý bol z hladiska výskumu najzaujímavejší, sme identifikovali vývoj tohto priestoru od 14. do 18. storočia. V prvej fáze priestor slúžil ako hlavná vstupná brána do hradného areálu z juhu. Kamenné ostenia objavené v oboch rohoch sondy 9A sú priamym dokladom existencie brány, avšak nevieme identifikovat' jej hornú čast'. Na pravej strane v stene je otvor, ktorý slúžil na uloženie klady, ktorá zvnútra uzatvárala bránu. Počas 15 . storočia bola brána niekol'kokrát 


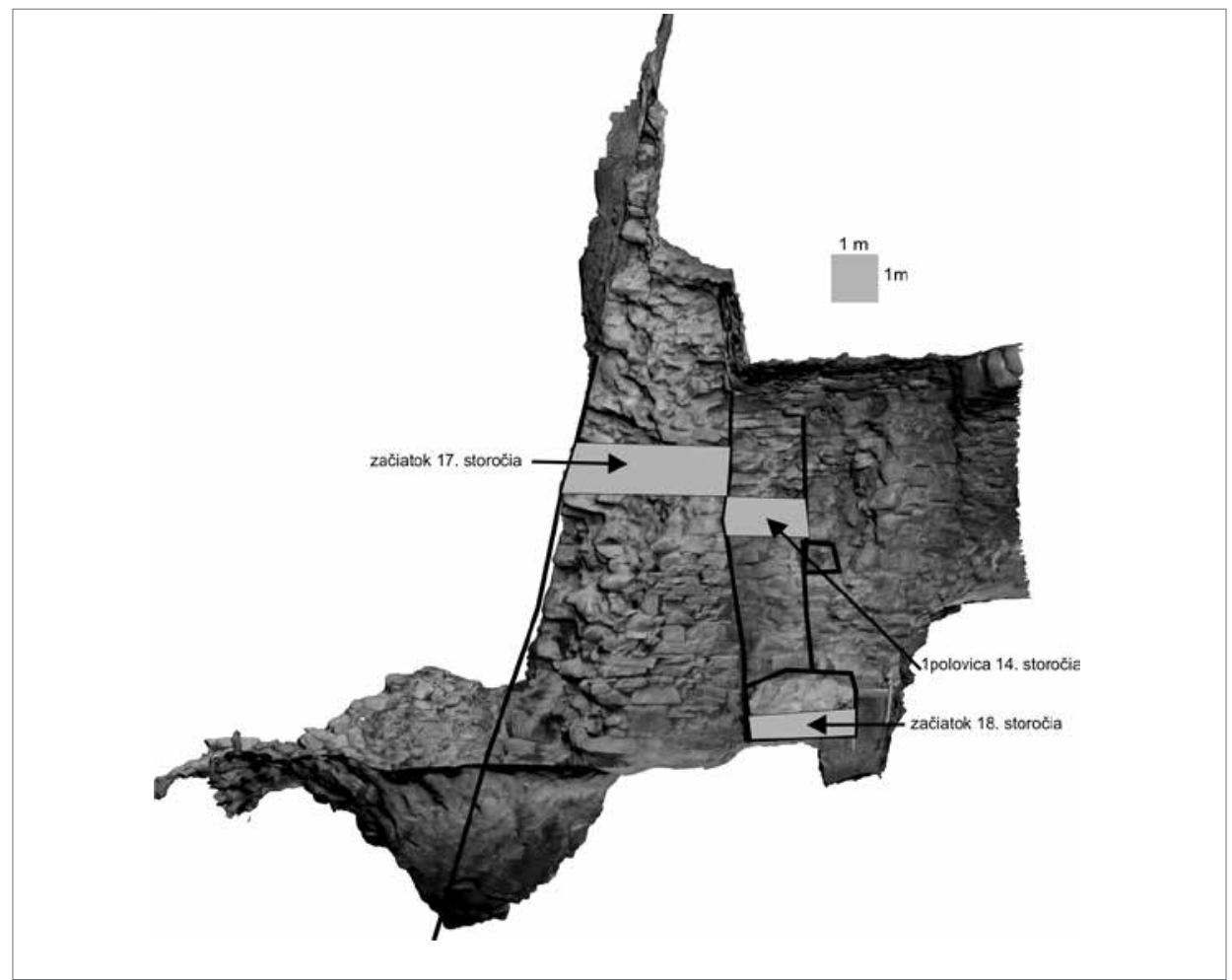

Obr. 4. Hrad Gýmeš, okr. Nitra. Rez gotickou bránou, sonda 9A. V programe Agisoft spracoval B. Balžán.

Abb. 4. Burg Gýmeš, Bezirk Nitra. Schnitt durch das gotische Tor, Sondierschnitt 9A. Mit dem Programm Agisoft erstellt von B. Balžán.

poškodená. Preto bol celý múr v priebehu 16. storočia prestavaný a zosilnený, o čom svedčí priame prepojenie gotického muriva s renesančným $\mathrm{v}$ priestore pravého ostenia brány. Na základe výskumu však doposial' nevieme identifikovat' nárožia renesančného opevnenia z vonkajšej strany. Zároveň vel'ký terénny zlom medzi prahom a terénom vnútri delového bastiónu otvára otázku vstupu. Do hradu sa vstupovalo po menšom moste alebo z násypovej rampy. Otázky môže objasnit’ až výskum vnútri delového bastiónu. V poslednej etape využívania tohto objektu v druhej polovici 17. a v 18. storočí objekt stratil fortifikačnú funkciu a stal sa skladom. Ked’že vchod bol príliš vel'ký, zamurovali ho tak, že dovnútra sa vstupovalo dverami širokými $100 \mathrm{~cm}$. Najmladšiu fázu nebolo možné preskúmat', pretože bola poškodená pádom klenby prvého podlažia (obr. 5).

\section{Sonda 10/2013}

Sonda sa nachádzala $\mathrm{v}$ skalnom tuneli medzi predbráním a renesančnou delovou baštou. Terén $\mathrm{v}$ mieste sondy tvorila rovná plocha s povrchom $\mathrm{z}$ udupanej hliny. Pri stene z lomového kameňa sa črtalo vystupujúce skalné podložie. Ciel’om sondy bolo zlepšit' komunikačný prechod medzi dvoma čast’ami hradu, pretože prechod bol iba $130 \mathrm{~cm}$ vysoký, bolo ho potrebné z dôvodu premiestňovania sute a transportu materiálu zvýšit' na $160 \mathrm{~cm}$. V celej ploche i híbke obdížnikovej sondy bola zistená len jedna súvislá vrstva, tvorená tmavohnedou ílovitou hlinou so sporadickým výskytom fragmentov keramiky, zvieracích kostí a drobných predmetov. V exteriéri pred kamenným tunelom sme prešli vrstvami kamennej deštrukcie, ktoré sme začistili a zakryli nasucho kladenými kameňmi. Tieto múriky budú bránit’ erózii profilov. 


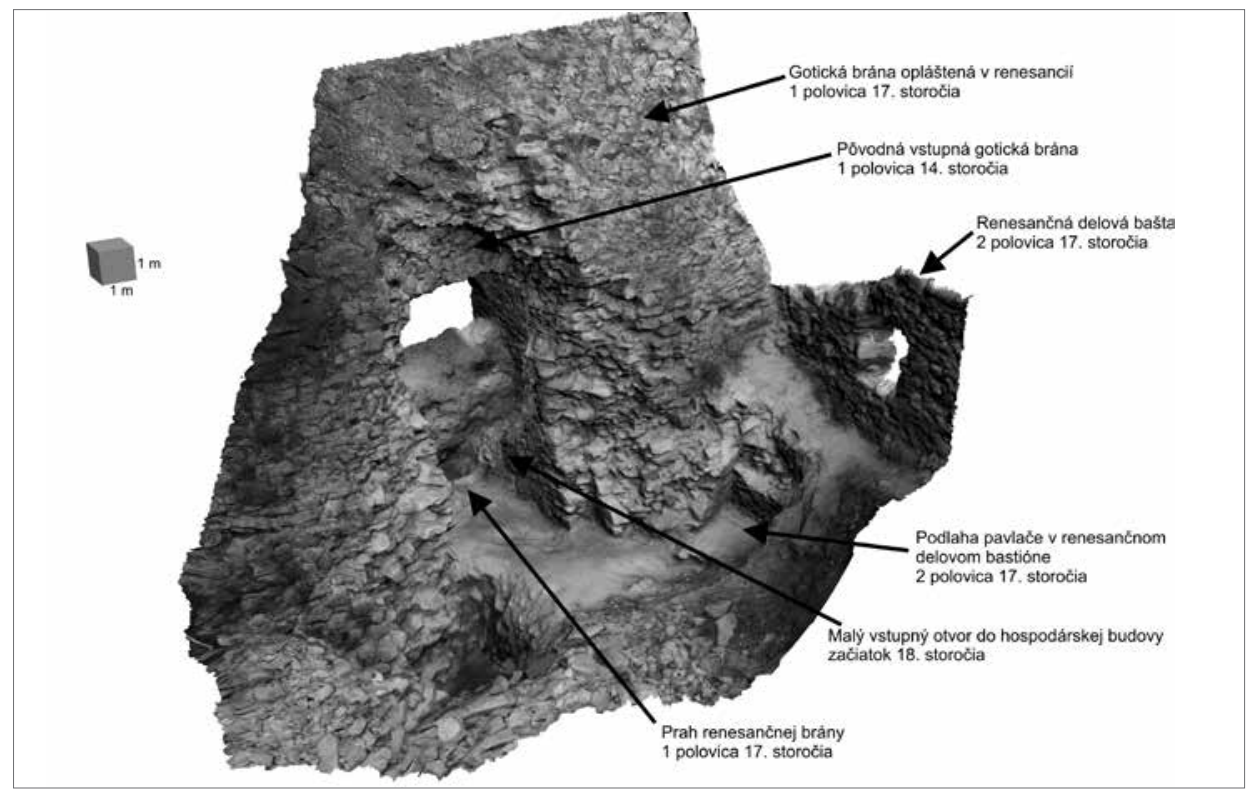

Obr. 5. Hrad Gýmeš, okr. Nitra. 3D pohl’ad na miesto archeologického výskumu v priestore pôvodného gotického vstupu (Sonda 9B). V programe Agisoft spracoval B. Balžán.

Abb. 5. Burg Gýmeš, Bezirk Nitra. 3D-Ansicht der archäologischen Grabung im Bereich des ursprünglichen gotischen Eingangs (Sondierschnitt 9B). Mit dem Programm Agisoft erstellt von B. Balžán.

\section{Sonda 11/2013}

Sonda sa nachádzala v hospodárskej budove horného hradu v severnej časti. Terén v mieste sondy tvoril prudký násypový kužel' z nádvoria do vstupného otvoru. Ciel’om prác v sonde bolo overit' existenciu vstupu, preskúmat' prah a vstupný otvor do hospodárskej budovy č. 5. Obdížniková sonda mala rozmery $100 \times 300 \mathrm{~cm}$ (obr. 6). Vrstva, ktorú sme prekopali a zdokumentovali, je terciárny zásyp priestoru pochádzajúci z nádvoria, ktorý obsahuje malé množstvo archeologických nálezov a tehly. Tie pochádzajú zo vstupnej klenby do priestoru hospodárskej budovy. Neobsahujú žiadne značky. Na dne sondy bol zachytený schod s rozmermi $200 \times 30 \mathrm{~cm}$ z kolmo ukladanej tehly. Tento schod vznikol asi až pri následnej prestavbe hospodárskej budovy v období baroka. V priestore vchodu sme identifikovali stopy po $20 \mathrm{~cm}$ širokej drevenej zárubni. Zároveň sme zistili, že schody pokračujú stupienkami vysekanými do skaly.

\section{Sonda 12/2013-2014}

Sonda sa nachádzala v najvýchodnejšej časti hradu pod Kaplnkou sv. Ignáca. Celkové rozmery sondy boli $900 \times 300 \mathrm{~cm}$, pričom sa delila na tri sektory A, B, C, rozdelené kontrolnými blokmi (šírka $50 \mathrm{~cm}$ ). Sektory A, B mali rozmer $150 \times 300 \mathrm{~cm}$, sektor C $500 \times 300 \mathrm{~cm}$. Terén tvorila rovná plocha s povrchom z udupanej hliny, pod ňou sa nachádzala sutová vrstva. Múr na východnej strane bašty je silne vytláčaný tlakom tejto hliny. Pod múrom sa nachádza prudký skalný zráz. Ciel'om sondy bolo odt'ažit' deštrukciu a odl'ahčit' východný múr bočného vstupu bránovej bašty. V celej ploche i híbke obdížnikovej sondy boli zistené štyri zásypové vrstvy, tvorené stavebnou sutou, tmavohnedou hlinou so sporadickým výskytom fragmentov keramiky, zvieracích kostí a železných klincov. Pod vrstvami stavebnej deštrukcie bola zachytená hnedá hlinená podlaha, pod ktorou sa v reze 2 ukázalo hrubé podložie vyplnené žltým ílom. V priestore vstupu do bašty boli zachytené dve etapy prahu, ktorý bol postupne navršovaný (obr. 7). Nad hlinitou podlahou sa nachádza jemná prepálená vrstva, súvisiaca pravdepodobne so spadnutým stropom dreveného podlažia bašty. Odstránením sute bola odhalená aj klúčová strielňa 


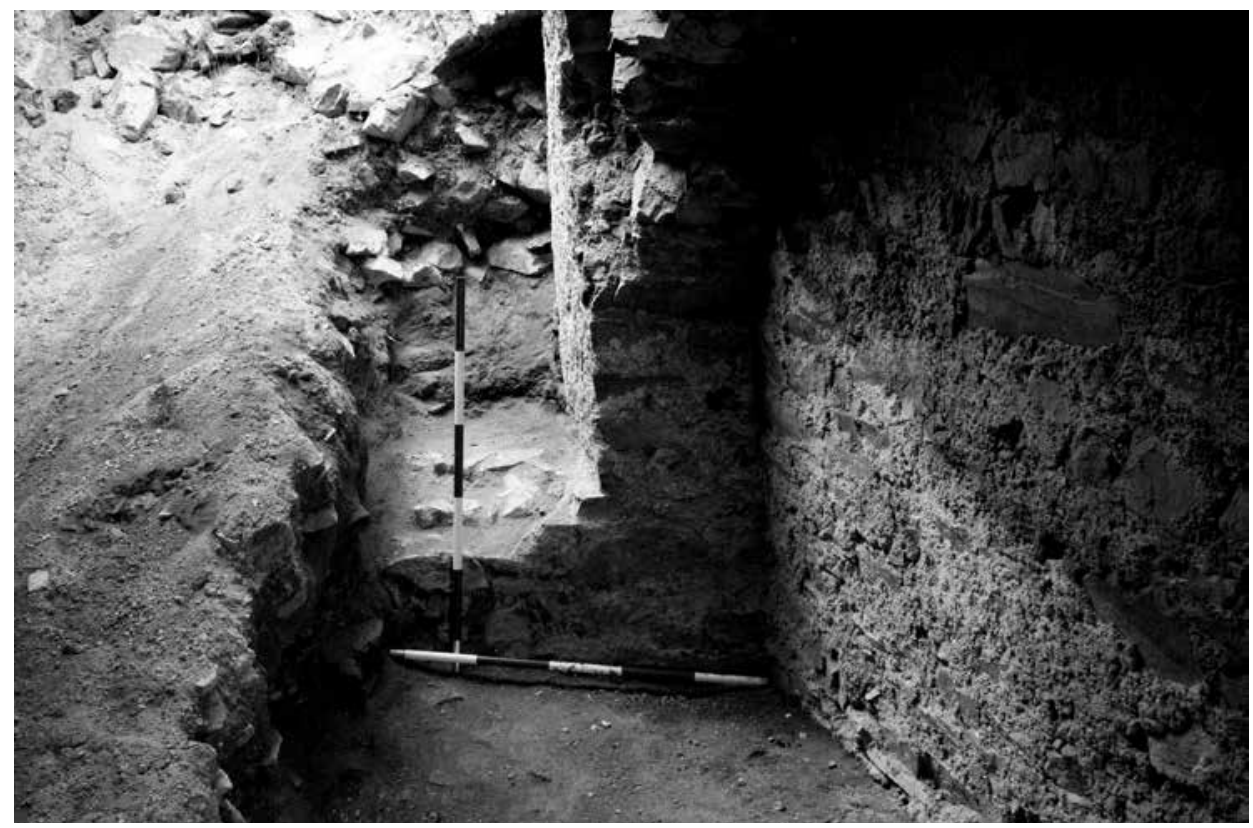

Obr. 6. Hrad Gýmeš, okr. Nitra. Sonda 11. Rez vstupom hospodárskej budovy č. 5. V skúmanom profile sme identifikovali iba sut'ové vrstvy.

Abb. 6. Burg Gýmeš, Bezirk Nitra. Sondierschnitt S11. Schnitt durch den Eingang des Wirtschaftsgebäudes Nr. 5. Im untersuchten Profil wurden nur Trümmerschichten identifiziert.

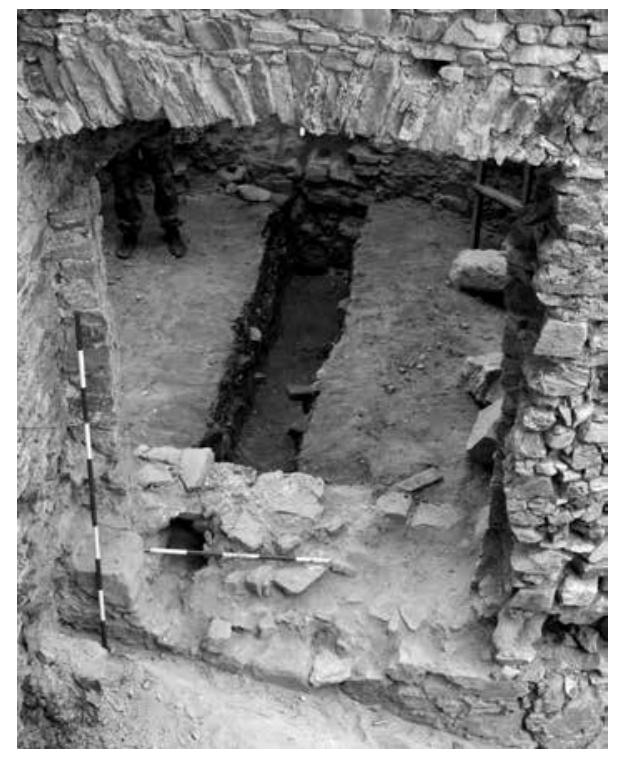

Obr. 7. Hrad Gýmeš, okr. Nitra. Sonda 12. Pohl'ad na parkánový vstup z východu.

Abb. 7. Burg Gýmeš, Bezirk Nitra. Sondierschnitt S12. Blick auf den Zwingereingang von Osten. v južnej stene bránovej bašty a okno vo východnej stene. $V$ priestore vstupu sme nenašli žiadne ostenia z brány. Tie by sa mohli nachádzat' $v$ priekope pred vstupom do bašty alebo v dôsledku erózie ležia niekde na východnom svahu hradného kopca. Vo východnej časti sondy $12 \mathrm{C}$ sme zachytili torzo východného múru parkánového vstupu, ktoré je silne zdeštruované a má šírku $100 \mathrm{~cm}$. V zásypových vrstvách sa nachádzalo malé množstvo keramiky, len niekol'ko menších fragmentov v terciálnych polohách je možné datovat' do vrcholného stredoveku.

\section{Analýza materiálu}

\section{Keramika}

Archeologický materiál bol doposial' analyzovaný iba čiastkovo. V roku 2013 sme získali 870 fragmentov keramiky. Z typologického hl'adiska sa $\mathrm{v}$ skúmanom súbore vyskytujú iba tieto typy nádob: hrniec, zásobnica, misa, džbán a pokrievka. V skúmanom súbore keramiky sme identifikovali tri časové horizonty. Najstaršiu keramiku predstavujú zlomky hrncovitej nádoby (obr. 10:1) a zásobnice (obr. 10:2). Od polovice 13. storočia sa v keramických súboroch v okolí Nitry objavujú vel'ké 


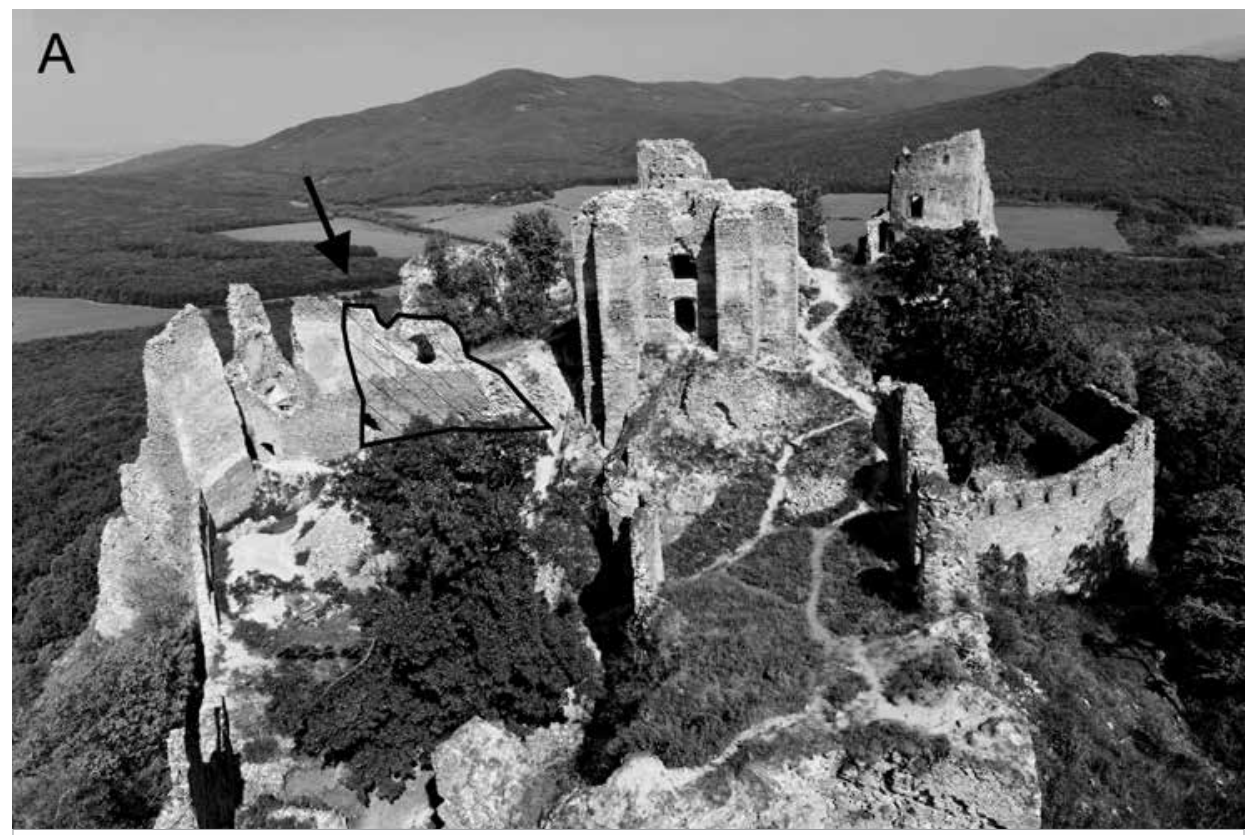

B

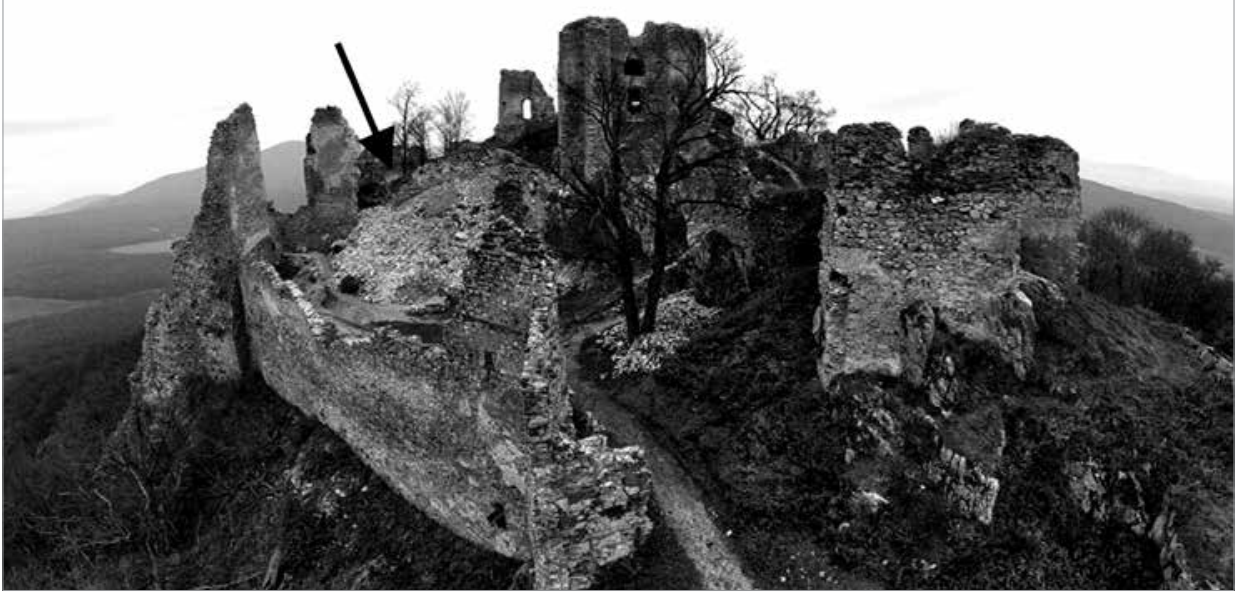

Obr. 8. Hrad Gýmeš, okr. Nitra. Deštrukcia južného múru juhozápadného paláca: A - stav v januári 2014, B - stav vo februári 2014. Archív Združenia Castrum Ghymes.

Abb. 8. Burg Gýmeš, Bezirk Nitra. Zerstörungsschicht der Südmauer des südwestlich gelegenen Palas: A - Zustand im Januar 2014, B - Zustand im Februar 2014. Archiv der Vereinigung Castrum Ghymes.

hrubostenné zásobnicové nádoby (Ruttkay 1995, 565). Tieto majú v hline vysoký podiel minerálnych štruktúr. Na pleciach nádoby sú často šikmé nechtové vrypy alebo vlnovky a línie vytvorené jednohrotým nástrojom. Táto skupina sa datuje do druhej polovice 13. až začiatku 14. storočia. Ďalší vel'ký súbor predstavujú nálezy z druhej polovice 14. až začiatku 15. storočia. Patria sem zvoncovité pokrievky s gombíkovitým úchytom (obr. 10:5, 6). Z typologického hl'adiska sa tu vyskytujú hrncovité nádoby s kyjakovitou hlavičkou (obr. 10:8). Na uchu hrncovitej nádoby sme identifikovali hrnčiarsku značku v tvare písmena X (obr. 10:10). S podobnými typmi 


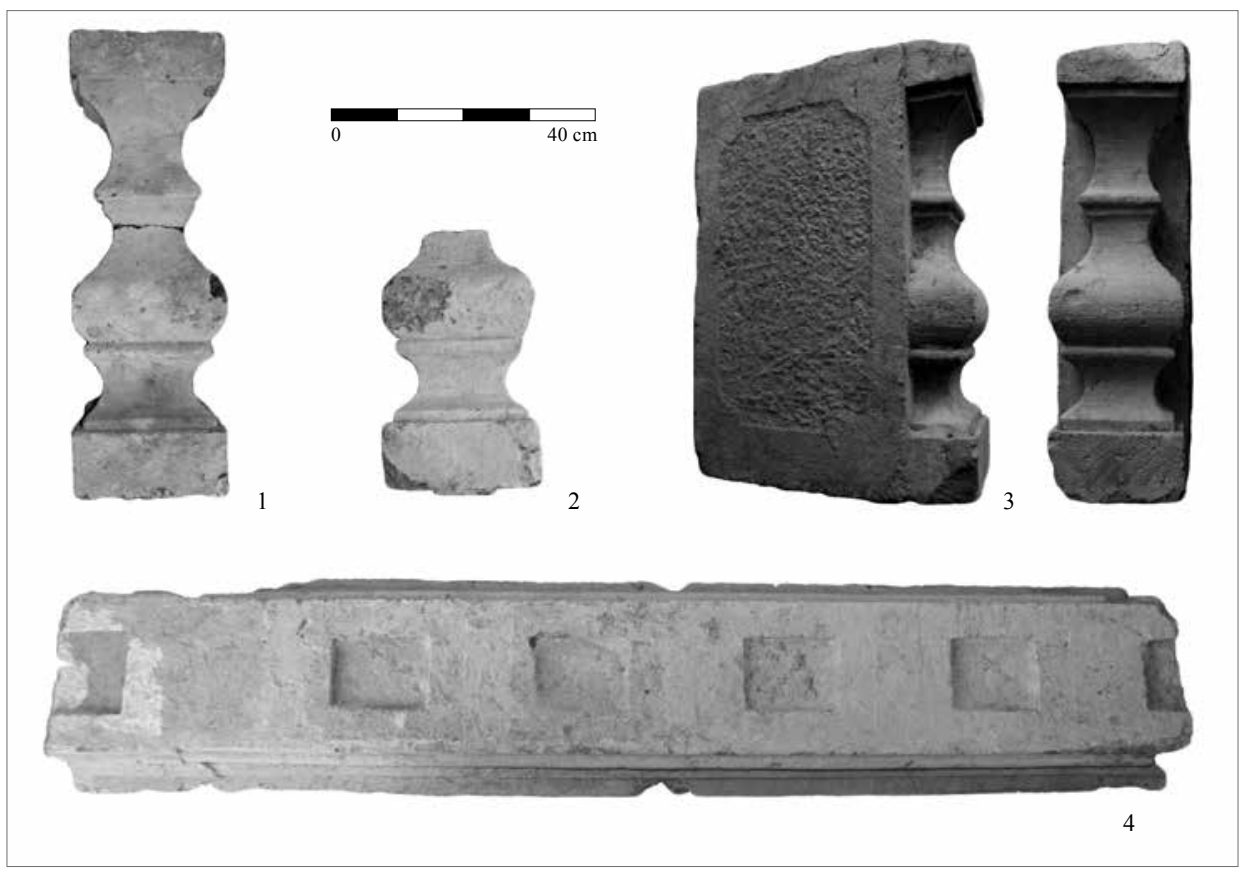

Obr. 9. Hrad Gýmeš, okr. Nitra. Kamenné balustrády a zvyšky schodiska v mieste deštrukcie južného múru juhozápadného paláca. Abb. 9. Burg Gýmeš, Bezirk Nitra. Steinbalustraden und Rest einer Treppe aus der Zerstörungsschicht der Südmauer des südwestlich gelegenen Palas.

nádob sa stretávame v Branči - Vel'kej Vsi, kde ich autor výskumu datuje na základe mincí do prvej polovice 15. storočia (Ruttkay 1995, 571-572). Najmladšiu skupinu predstavuje keramika druhej polovice 16. až 17. storočia. Vyskytuje sa tu redukčne pálená keramika tzv. „tvrdomestského typu“", ktorá sa objavuje na konci druhej polovice 16. storočia na strednom Ponitrí (Plicková $1959,51-52$ ) a pretrváva až do prvej polovice 18. storočia (obr. 10:3). Výroba tejto keramiky mala viaceré archaické prvky. Na keramike sa neobjavuje glazúra ani engoba. Keramika je vypálená $\mathrm{v}$ redukčnom prostredí $\mathrm{s}$ výzdobou, ktorá bola vyhotovená väčšinou jednohrotým nástrojom alebo radielkom. V skúmanom súbore sa nachádza vel'mi málo glazovaných fragmentov (20 zlomkov).

\section{Kachlice}

Vel'mi zaujímavú skupinu nálezov predstavujú kachlice. Nádobkové kachlice z hradu majú štvorcový vyhrievací otvor a všetky sú oxidačne vypálené do tehlovočervena. V súbore kachlíc dominujú komorové kachlice, ktoré môžeme rozdelit' na gotické a renesančné. Gotické kachlice boli objavené iba $\mathrm{v}$ sonde 12 a pochádzajú pravdepodobne z gotického paláca pri Kaplnke sv. Ignáca. Ide o komorové kachlice s figurálnymi motívmi. Na prvej kachlici je zobrazený lev s hrivou a drápmi na predných nohách (obr. 11:1). Lev drží v jednej labe jeden a pol ručný krátky meč. Po obvode kachlice sa nachádza gotický nápis, ktorý sa nám nepodarilo zatial' rozlúštit'. Lev bol oddávna znamením sily, ktorá mala pozitívny aj negatívny aspekt. Ako symbol Krista vyjadruje jeho zmŕtvychvstanie. Stredoveká symbolika v ňom videla kontrast Kristovej božskej a l'udskej podstaty (Heinz-Mohr 1971, 134). Na gotických kachliciach zo Slovenska je zobrazený jednochvostý heraldický lev stojaci na zadných nohách. Predné nohy má natiahnuté dopredu a ukončené štylizovanými pazúrmi. Lev je otočený doprava, s výnimkou kachlice z Kežmarku (Polla 1971, 113). Krk leva je pokrytý hrivou, z tlamy mu trčí vyplazený jazyk a na hlave má 

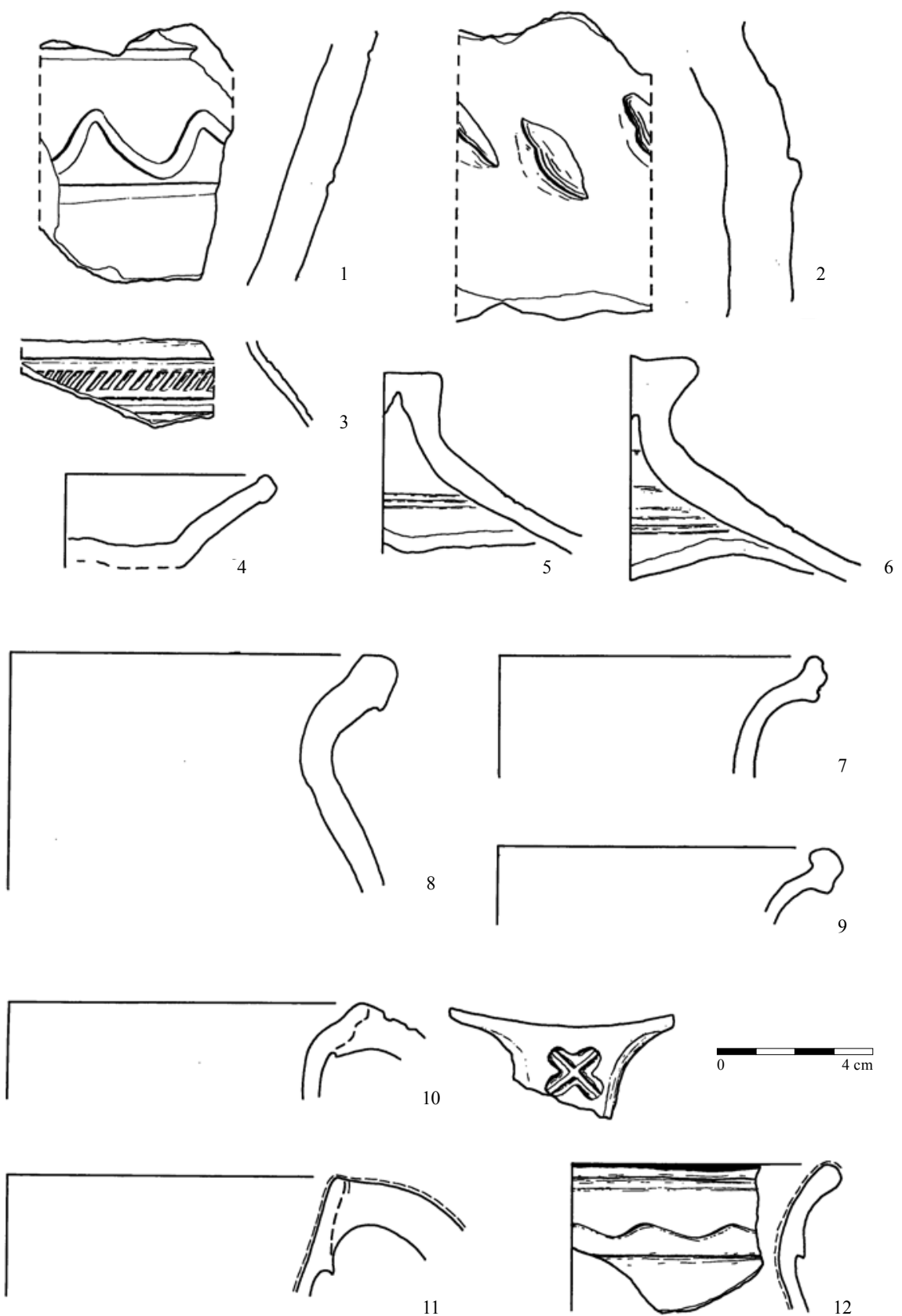

Obr. 10. Hrad Gýmeš, okr. Nitra. Výber stredovekej a novovekej keramiky z archeologického výskumu. Kresba Ž. Nagyová.

Abb. 10. Burg Gýmeš, Bezirk Nitra. Auswahl an mittelalterlicher und neuzeitlicher Keramik aus den archäologischen Grabungen. Zeichnung Ž. Nagyová. 


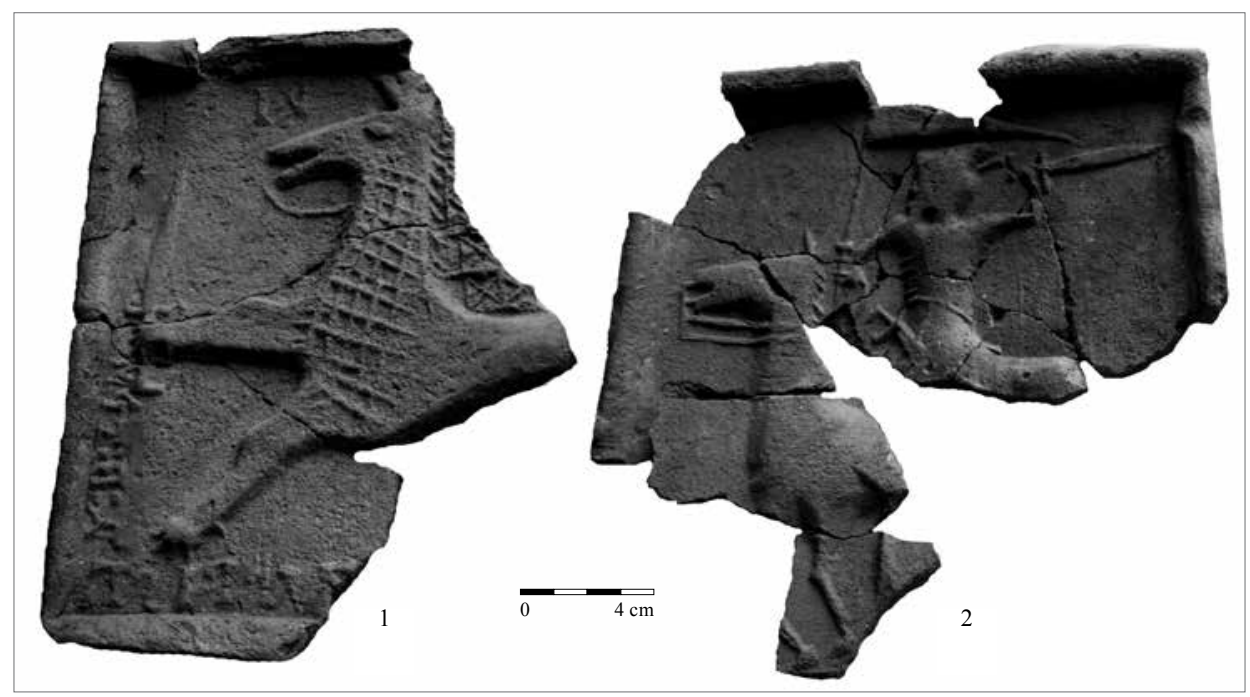

Obr. 11. Hrad Gýmeš, okr. Nitra. Výber gotických kachlíc zo sondy 12A.

Abb. 11. Burg Gýmeš, Bezirk Nitra. Auswahl an gotischen Ofenkacheln aus Sondierschnitt 12A.

korunu. Nálezy kachlíc zo Slovenska zobrazujúce leva pochádzajú z týchto lokalít: Bratislavský hrad (Holčík 1976, 98, obr. 10 ), Banská Bystrica (Mácelová 1999, 417), Devín (Plachá-Hlavicová 2003, 113), Kežmarok - hrad (Polla 1971, 113), Levice - hrad (Drenko 1974), Červený Kameň (Holčík 1978), Šášov - hrad a Topol’čianky (Ruttkay 2008, 199, B92). Druhá gotická kachlica zobrazuje jazdca so zástavou, ktorý drží v l’avej ruke meč, s ktorým sa zaháňa (obr. 11:2). Jazdec na koni nesúci zástavu je typickým príkladom rytiera v turnajovej zbroji. Samostatnú kategóriu výskumu predstavujú štíty rytierov. Často zobrazujú rodové symboly, hlavne u kachlíc z Nemecka a Česka. U nás v rytierskej problematike prevláda zobrazovanie tzv. budinskej dielne (Holčík 1978, 124, 29-30). Renesančné kachlice sú zastúpené základnými typmi, ktoré sa objavujú na juhozápadnom Slovensku. Ide najmä o tapetovité motívy s prekríženými srdcami (obr. 12:2), motívy rozety v renesančnom kruhu (obr. 12:3), geometrické motívy (obr. 12:6) a motív habsburskej orlice (obr. 12:5). V súbore sa nachádza aj jedna vrcholová kachlica (obr. 12:1), ktorá pochádza zo štítu kachlovej pece. Všetky renesančné kachlice sú v lome tehlovočervenej farby. Kachlice boli vypálené v oxidačnom prostredí. Výzdoba plôch alebo pásov založená na pravidelnom opakovaní sa nazýva raport alebo tapetovitý, či kobercovitý vzor (Pavlík-Vitanovský 2004, 180). Tapetovitý vzor sa na kachliciach objavuje na konci 15. storočia a používa sa s malými obmenami až dodnes. Vzory rozdel'ujeme na geometrické, rastlinné a orientálne kombinácie. S obl'ubou sa napodobňujú rôzne textilné vzory (Teppichmuster), ktoré vypíňajú celú čelnú plochu kachlice (Egyházy-Jurovská 2001, 40-43). Tapetovité kachlice sú kombináciou geometrických a rastlinných motívov. Plocha reliéfu je členená páskou a tvorí základnú kompozičnú siet. Obrazce, ktoré vzniknú v ploche, vyplňujú rastlinné prvky. Jedna skupina je tvorená páskou, ktorá je rozvinutá do tvaru srdca, ktorý sa rozdel'uje do niekol'kých kombinácií. Vnútri srdca sa nachádzajú rôzne vegetačné motívy (viničný alebo akantový list, rozetka, dobový list). V renesančnej a barokovej symbolike je srdce obrazom nebeskej a pozemskej lásky (Heinz-Mohr 1971, 243).

\section{Drobné predmety}

Počas výskumu sme získali aj malé množstvo drobných predmetov, ktoré môžeme rozdelit’ na dve základné skupiny. Najväčšiu skupinu nálezov tvoria železné kované klince ( $321 \mathrm{ks})$. Vel'kost' klincov sa pohybuje od 6 do $12 \mathrm{~mm}$. Väčšina nálezov pochádza z priestoru bočného parkánového vstupu. Tvorili pravdepodobne súčast' trámovej konštrukcie nad vstupom a sú tu 


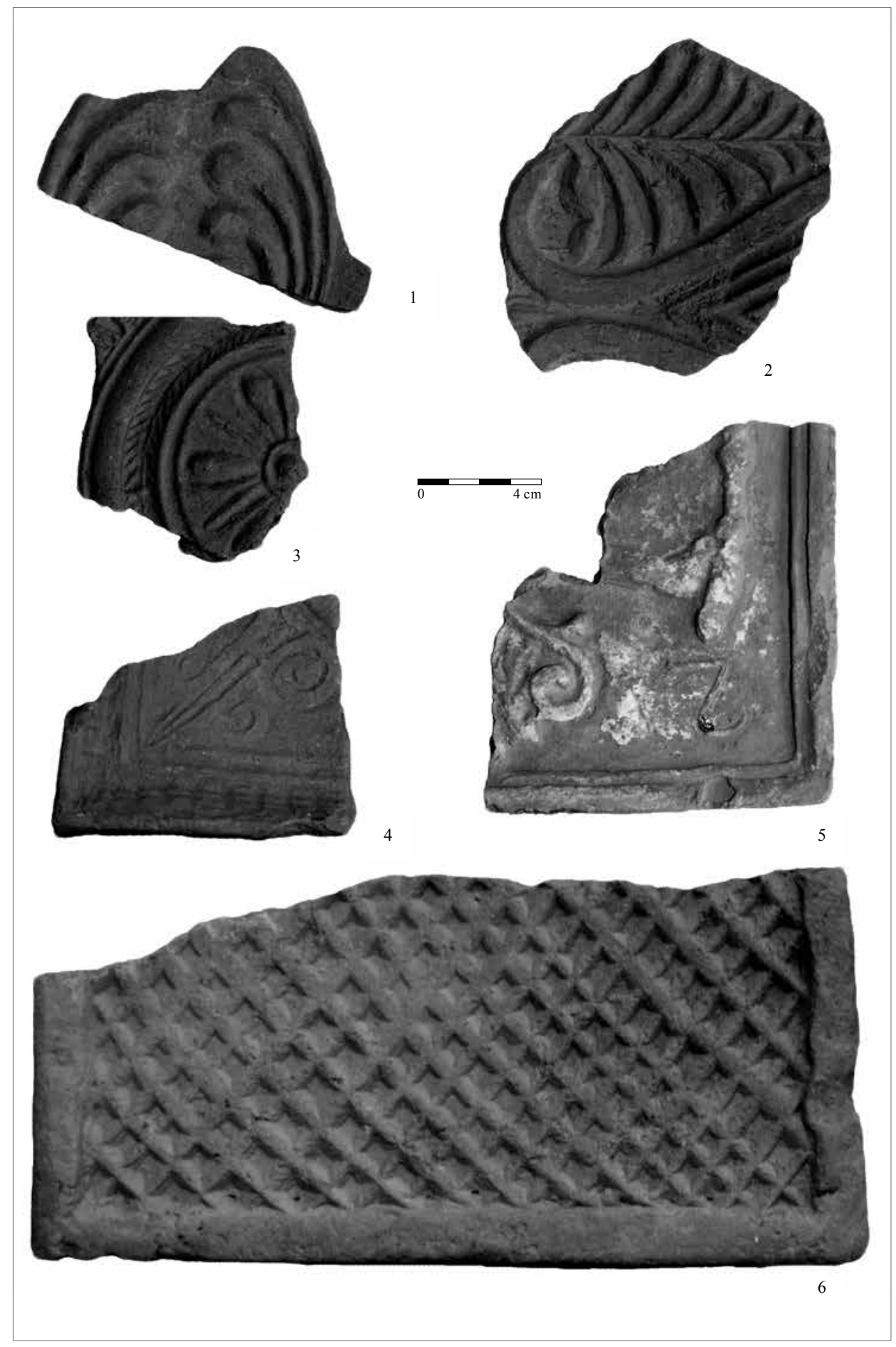

Obr. 12. Hrad Gýmeš, okr. Nitra. Výber renesančných kachlíc z výskumu.

Abb. 12. Burg Gýmeš, Bez. Nitra. Auswahl an Renaissancekacheln aus den Grabungen. 
aj sekundárne transportované nálezy (?) z priestoru okolia Kaplnky sv. Ignáca alebo z jej konštrukčných prvkov. Nálezy klincov pri pôvodnej gotickej vstupnej bráne súvisia s najmladšou fázou využívania objektu, ked' slúžil ako sklad. Druhú vel'kú skupinu tvoria nálezy skla, ktoré delíme na zlomky tabul'ového skla a skla z drobných nádob. Sklo je zastúpené približne 121 fragmentmi. Ide o nádoby spojené so stolovaním (zlomky pohárov, drobných sklenených nádob). Väčšinu nádob môžeme datovat' do obdobia renesancie. Medzi sklenenými nádobami sa stretávame zatial' iba s čírym sklom. Počas výskumu sme zberom pri Kaplnke sv. Ignáca objavili jednu denárovú mincu Rudolfa II. z roku 1595, typu Halačka (1987, 198, č. 380; určil J. Hunka).

Pri deštrukcii južného múru gotického juhozápadného paláca sa podarilo zo sutín vytiahnut' dvanást' kusov opracovaných pieskovcových kameňov (obr. 8). Ide o zvyšky zábradlia kamenného schodiska. Identifikovali sme kamenné balustrády (obr. 9:1, 2) a sokel balustrád. Jednotlivé balustrády boli vysoké $60 \mathrm{~cm}$. Vzdialenost' balustrád v sokli bola $20 \mathrm{~cm}$ (obr. 9:4). Kamenné schodisko sa pravdepodobne nachádzalo medzi prvým a druhým podlažím juhozápadného palácového krídla horného hradu. V sonde 12 bolo objavených štrnást' fragmentov mazanice, na ktorých boli otlačky opracovaných foršní. Hrúbka hlineného omazu bola do $4 \mathrm{~cm}$. Ide pravdepodobne o omaz nejakej zvislej konštrukcie, nejde o stropnú konštrukciu. Počas výskumu sme získali aj menšie množstvo zvieracích kostí: tura domáceho, svine domácej, ovce a kury (určil Z. Vozák).

\section{Záver}

Archeologický výskum v rokoch 2013 a 2014 na hrade Gýmeš sa zameral hlavne na dva objekty, pôvodnú vstupnú gotickú bránu a bočný parkánový vstup. Oba objekty prešli mnohými prestavbami. Výskum sa uskutočnil súbežne s architektonicko-pamiatkovým výskumom M. Bónu (2014). Postupne sme preskúmali štyri sondy (S9, S10, S11, S12), pričom sondy S9 a S12 sme doskúmali aj v roku 2014. Sonda 9 bola situovaná v priestore pôvodnej vstupnej gotickej brány (obr. 4, 5). Architektonický výskum predpokladal tri hlavné etapy vývoja vstupu, čo potvrdil aj archeologický výskum. Brána vznikla v priebehu prvej polovice 14. storočia, ked' tvorila hlavný vstup do hradu. V nasledujúcich storočiach bola značne poškodená. K jej zosilneniu došlo na začiatku 17. storočia ako priamy dôsledok tureckého ohrozenia. Toto výrazné posilnenie opevnenia bolo spojené s palatínom Žigmundom Forgáčom. V tomto období došlo aj k vybudovaniu vel'kého delového bastiónu. Brána stratila svoju vojenskú funkciu. Ani tieto stavebné úpravy však nezabránili vyplieneniu hradu vojskami Gabriela Betlena v roku 1619 a neskôr hrad dobyli Osmani. Turci sídlili na hrade v rokoch 1663-1671. Posledné stavebné úpravy spájame so začiatkom 18. storočia a realizoval ich v barokovom duchu Pavol IV Forgáč a neskôr aj jeho syn. Hlavný vstup bol zmenšený a priestor bol premenený na skladisko. Sonda 10 sa nachádzala v priestore skalného tunela medzi vel'kým delovým bastiónom a nádvorím za barokovou vstupnou bránou. V zásype sa objavilo minimum archeologických nálezov. Sonda 11 skúmala vstup do hospodárskeho priestoru horného hradu v severnej časti. Došlo k odkrytiu jedného tehlového schodu a zásypu z nádvoria pred hospodárskou budovou. Sonda 12 bola situovaná v parkánovom vstupe pod Kaplnkou sv. Ignáca. Sondu sme rozdelili na tri priestory a postupne sme ich skúmali. Vo februári 2014 došlo k deštrukcii južného múru juhozápadného paláca horného hradu. V kuželi deštrukcie sme identifikovali dvanást' kamenných opracovaných článkov, ktoré pochádzajú z barokového schodiska vnútri paláca (obr. 9). Kvôli vandalizmu sme tieto články vybrali a zdokumentovali. $Z$ archeologického výskumu pochádza keramický materiál, ktorý sme zatial' len čiastkovo zanalyzovali. Medzi nálezmi sa objavuje keramika, kachlice, drobné železné predmety a sklo. Nálezy dokumentujú históriu hradu od 13. do 16. storočia. Výskum je rozsahom zatial' vel'mi malý, ale priniesol niekol'ko nových poznatkov doplňujúcich stavebno-historický výskum. Výskum oboch objektov by mal pokračovat' aj v roku 2015. 


\section{Literatúra}

BÓNA, M., 1995: Sakrálne stavby hradu Gýmeš, Pamiatky a múzeá, č. 2, 30-32.

- 1996: Renesančné a barokové prestavby hradu Gýmeš, Pamiatky a múzeá, č. 4, 28-31.

- 2003: Hrad Gýmeš a kultúrne pamiatky obce Jelenec. In: Fehér, A. a kol., Jelenec: monografia, 152-214. Bratislava.

- 2003a: Heslo Hrad Gýmeš. In: Buran, D. a kol., Gotika. Dejiny slovenského výtvarného umenia, 580-581. Bratislava.

- 2006: Sakrálny okrsok Gýmešského hradu ako súčast' neskorobarokovej prestavby hradného komplexu. In: Umenie na Slovensku v historických a kultúrnych súvislostiach 2005, 89-101. Trnava.

- 2007: heslo Gýmeš. In: Plaček, M.-Bóna, M., Encyklopédia slovenských hradov, 121-124. Bratislava.

- 2011: Hrad Gýmeš. Stručný sprievodca po zrúcanine hradu. Bratislava.

- 2014. Doplnkový architektonicko-historický výskum v objektoch predbránia a hradného paláca III. Zlaté Moravce.

BÓNA, M.-LUKAČKA, J., 2002: Úloha hradov horného Ponitria a Požitavia pri obrane a osídlení územia do konca 14. storočia - Aufgabe der Burgen in der Gegend am Oberlauf der Flüsse Nitra und Žitava bei der Verteidigung und bei der Besiedlung dieses Gebiets bis Ende des 14. Jhs, AH 27, 239-268.

DRENKO, Z., 1974: Nálezová správa z archeologického výskumu Levického hradu č. 6987/1974 ulož. v AÚ SAV v Nitre.

EGYHÁZY-JUROVSKÁ, B., 2001: Renesančné kachlice na Slovensku, Pamiatky a múzeá, č. 4, 40-42.

ELIÁŠ, M., 2011: Forgáchovci. Šl'achtický rod z Gýmeša. Jelenec.

FÜGEDI, E., 1986: Castle and Society in Medieval Hungary. Budapest.

HALAČKA, I., 1987: Mince Zemí koruny české 1526-1856. I. Kroměříž.

HEINZ-MOHR, G., 1971: Lexicon der Symbole. München.

HOLČÍK, Š., 1976: Stredoveké kachlice na Slovensku, ZbSNM 70, História 16, 91-113.

- 1978: Stredoveké kachlice. Bratislava.

JAŠŠO, F., 2011: Nálezová správa z archeologického výskumu hradu Gýmeš v roku 2011 ulož. v Pamiatkovom úrade Slovenskej republiky, Bratislava.

KATKIN, S.-BÓNA, M., 2000: Záchranný výskum v kaplnke hradu Gýmeš. In: AVANS 1998, $113-115$. Nitra.

KÖNYÖKI, J., 1905: A középkori várak, különleges tekintettel Magyarországra. Budapest.

LUKAČKA, J., 2003: Rod Forgáčovcov do polovice 15. storočia, Historický zborník 13, č. 1-2, 66-79.

MÁCELOVÁ, M., 1999: Gotické kachl'ové pece z banskobystrickej radnice - Die gotischen Kachelofen aus dem Rathaus in Banská Bystrica, AH 24, 409-420.

MENCLOVÁ, D., 1973: Príspevok k typológii hradov, zámkov a kaštiel’ov na Slovensku. In: Pisoň, Š., Hrady, zámky a kaštiele na Slovensku, 397-445. Bratislava.

MEDNYÁNSZKY, A., 1821: Ghymes váranak leirása, Tudományos Gyüjtemény 2, 36-46.

PAVLÍK, Č.-VITANOVSKÝ, M., 2004: Encyklopedie kachlů v Čechách, na Moravě a ve Slezsku. Praha.

PLACHÁ, V.-HLAVICOVÁ, J., 2003: Devín. Slávny svedok našej minulosti. Bratislava.

PLICKOVÁ, E., 1959: Pozdišovské hrnčiarstvo, 51-52. Bratislava.

POLLA, B., 1971: Kežmarok. Výsledky historicko-archeologického výskumu. Bratislava.

RUTTKAY, M., 1995: Príspevok k poznaniu stredovekej keramiky na juhozápadnom Slovensku - Beitrag zur Erkenntnis der mittelalterlichen Keramik in der Süd-West-Slowakei, AH 20, 563-584.

- 1997: Die Grundveränderungen in der Keramikproduktion im 12.-14. Jh. in der Westslowakei, Pravěk NŘ 6, 261-284.

- 2008: Kachlice z hradu v Topol'čiankach, ŠZ 41, 123-233.

\section{Zusammenfassung}

\section{Die archäologischen Grabungen auf Burg Gýmeš in den Jahren 2013-2014}

Ziel des vorliegenden Beitrags ist es, die Ergebnisse der in den Jahren 2013 und 2014 auf der Burg Gýmeš durchgeführten archäologischen Grabungen zu präsentieren. Die Grabungen erfolgten parallel zu der archiktonisch-denkmalpflegerischen Untersuchung von M. Bóna und knüpfte methodisch an die von F. Jaššo im Jahr 2011 durchgeführte Grabung an. Wir haben schrittweise vier Sondierschnitte untersucht (S9, S10, S11, S12), wobei die Sondierschnitte S9 
und S12 auch im Jahr 2014 untersucht wurden. Sondierschnitt S9 lag im Bereich des ursprünglichen gotischen Eingangstores (Abb. 4, 5). Die architektonische Untersuchung ging dabei von drei Hauptentwicklungsetappen aus, was von den archäologischen Grabungen auch bestätigt wurde. Das Tor entstand in der ersten Hälfte des 14. Jahrhunderts, als es den Haupteingang zur Burg bildete. In den darauffolgenden Jahrhunderten wurde es dann sehr beschädigt. Zu Beginn des 17. Jahrhunderts wurde es als direkte Auswirkung auf die Türkenbedrohung verstärkt. In dieser Zeit kam es auch zur Errichtung der großen Renaissancebastion. Das Tor verlor seine militärische Funktion. Der Haupteingang wurde verkleinert und zu einem Lager umfunktioniert. Sondierschnitt S10 befand sich im Bereich des Felsentunnels. Mit Sondierschnitt S11 wurde der Eingang zum Wirtschaftsbereich in der oberen Burg untersucht (Abb. 6), und Sondierschnitt S12 lag im Zwingereingang unter der St. Ignazkapelle (Abb. 7). Im Februar 2014 kam es zur Zerstörung der Südmauer des südwestlich gelegenen Palas der oberen Burg. Im Zerstörungskegel haben wir zwölf bearbeitete Steinelemente identifiziert, die von einer barockzeitlichen Treppe des inneren Palas stammen (Abb. 9). Bei den archäologischen Grabungen wurde Keramikmaterial entdeckt, das wir bisher nur teilweise analysiert haben. Zu den Funden gehören Keramik, Ofenkacheln, kleine Metallgegenstände und Glas. Von den Funden wird die Geschichte der Burg vom 13. bis zum 16. Jahrhundert dokumentiert. Ihrem Umfang nach waren die Grabungen bislang nur sehr gering, lieferten aber eine Fülle an Informationen über die Entwicklung der Burg, durch welche die von M. Bóna durchgeführte bauhistorische Untersuchung bestätigt werden. An beiden Objekten werden die Grabungen auch im Jahr 2015 fortgesetzt.

Der vorliegende Beitrag entstand im Rahmen des Förderprojekts VEGA 02-189-12.

Mgr. Mário Bielich, Ph.D., Archeologický ústav SAV, Akademická 2, SK 94921 Nitra, Slovenská republika,nraumbie@savba.sk

Mgr. Jozef Elgyütt, Archeologický ústav SAV, Akademická 2, SK 94921 Nitra, Slovenská republika, jozef.elgyutt@savba.sk 
